(c) Taylor \& Francis Group, LLC

The original publication is available at http://www.tandf.co.uk/journals/

\title{
Optimization of common cuttlefish (Sepia officinalis) protein hydrolysate using Pepsin by Response Surface Methodology
}

Emna Soufi Kechaou ${ }^{a, c,{ }^{*}, \text { Jean-Pascal Bergéb }}{ }^{\text {, Pascal Jaouen }}{ }^{a}$ and Raja Ben Amar ${ }^{c}$

\author{
a Université de Nantes, GEPEA UMR-CNRS 6144, BP 406, 44602 , Saint-Nazaire , France \\ ${ }^{\mathrm{b}}$ IFREMER, Département STAM, BP 1105, Nantes, France , 44311 \\ ${ }^{c}$ Faculté des Sciences de Sfax Laboratoire des Sciences des Matériaux et Environnement, route de Soukra km \\ 4- 3018 Sfax, Tunisia \\ *: Corresponding author : Emma Soufi Kechaou, tel. +219-27424294 ; \\ email address : emna.soufi-kechaou@univ-nantes.fr
}

\begin{abstract}
:
Protein hydrolysate was prepared from common cuttlefish Sepia officinalis by Pepsin. Hydrolysis conditions (time, temperature, and enzyme activity) were optimized by response surface methodology (RSM) using a factorial design. The regression coefficient was close to 0.999 , observed during both experimental and validation runs, and indicated the validity of prediction model. An enzyme activity to substrate ratio (X1), $0.04 \mathrm{AU} / \mathrm{g}$ protein; time (X2), 85 minutes; and temperature $(\mathrm{X} 3), 45^{\circ} \mathrm{C}$ were found to be the optimum conditions for a higher degree of hydrolysis (21\%) and nitrogen recovery $(90 \%)$ using Pepsin. According to amino acid analysis results and chemical score, methionine and histidine are the limiting amino acids in the hydrolysates, in that order. All other amino acids are present in sufficient quantity as required.
\end{abstract}

Keywords: Cuttlefish Protein Hydrolysate (CPH) ; Sepia officinalis ; Enzyme ; amino acid 


\section{ACCEPTED MANUSCRIPT}

\section{Introduction}

The cephalopods (cuttlefish, common octopus, and squid) are an important economic resource for global fisheries. Cuttlefish is mainly exported frozen from the Mediterranean countries to Japan. France is the second most important exporter of frozen cuttlefish in the European Union. Cuttlefish viscera represent an important part of the cuttlefish mass (15-25\%). So, their waste represents an important commercial loss. Enzymatic protein hydrolysis is a promising process for underutilized marine products. Fish protein hydrolysates from various sources have been studied extensively and described by several researchers (Kristinsson and Rasco 2000a,b; Liaset et al., 2000; Nilsang et al., 2005; Bhaskar et al., 2007, Ovissipour et al., 2009). Enzymatic hydrolysis allows production free amino-acids, so nitrogen can be more soluble (Espe et al., 1989; Vidotti et al., 2003). Also, such hydrolysates can be utilized as ingredients in aquacultural feed (Vidotti et al., 2003; Nilsang et al., 2005) and as effective nitrogen sources for microbial growth media (Guerard et al., 2001). An addition of exogenous enzymes could make the hydrolytic process more controllable, thereby making it reproducible. Commercial enzymes have often been used for fish hydrolysis due to the high degree of hydrolysis (DH) reached in a relatively short time compared to autolysis (Je et al., 2004; Kim et al., 2001). Depending on the specificity of the enzyme, environmental conditions, and the extent of hydrolysis, a wide variety of peptides will be generated. The resultant protein hydrolysate will possess particular properties according to the new peptides generated. Several factors, like $\mathrm{pH}$, time, enzyme activity, and temperature, influence enzyme function, offering possibilities to control the process (Viera et al., 1995; Liaset et al., 2000). In recent years, cephalopoda have been studied only to a minor extent

\section{ACCEPTED MANUSCRIPT}




\section{ACCEPTED MANUSCRIPT}

in terms of enzymatic hydrolysis. The cuttlefish Sepia officinalis viscera have been studied only in terms of autolysis (Le Bihan et al., 2006). However, fish enzymes have been widely studied in terms of structural modification, functional properties, biological activities, and lipid and phospholipid recoveries (Kim and Lee, 1987; Quaglia and Orban, 1990; Zhang and Takeshi, 1994; Ravallec-Ple' et al., 2001; Dumay et al., 2006; Otani et al., 2009). However, an optimization of the protein hydrolysate production from cuttlefish has not been reported.

The present investigation was undertaken to evaluate the usefulness of Sepia officinalis viscera as a source of recoverable proteins in the form of protein hydrolysate. The aim of the study was to optimize reaction conditions (time, temperature, and enzyme activity) in order to obtain an optimal degree of hydrolysis of cuttlefish proteins (Sepia officinalis) using commercial Pepsin. The amino acid composition of the protein hydrolysate achieved at optimum conditions and its chemical score were determined as well.

\section{Materials and methods}

\subsection{Biological Material}

Cuttlefish (Sepia officinalis) were provided by the seafood processing company "Calembo" (Sfax, Tunisia). The collected viscera were homogenized for $1 \mathrm{~min}$ and then frozen at $-80^{\circ} \mathrm{C}$ until used. Endogenous enzymes were not inactivated. The cuttlefish viscera fraction included all the organs usually found in the abdomen of mature specimens.

\section{ACCEPTED MANUSCRIPT}




\section{ACCEPTED MANUSCRIPT}

\subsection{Enzymatic material}

The Pepsin (EC 3.4.23.1) was provided by DSM. Unlike other endopeptidases, Pepsin hydrolyzes only peptidic bonds (not amide or ester links). Pepsin has broad specificity, with a preference for peptides containing linkages with aromatic or carboxylic L-amino acids. It preferentially cleaves the C-terminal to phenylalanine and leucine. The optimal temperature for Pepsin given by the supplier is between 45 and $50^{\circ} \mathrm{C}$, which is suitable for industrial and preindustrial applications since it is not high in energy consumption. Pepsin generates non-bitter peptides; this is suitable for applications in animal feeding. Moreover, it also has been reported that Pepsin hydrolysates show a chemoattractant potential as a feed ingredient (Lian et al., 2001).

\subsection{Hydrolysis design}

The frozen and minced viscera were kept at $4^{\circ} \mathrm{C}$ for one night for thawing and homogenized with MilliQ-purified water (ratio: 1/1, w/v). For each hydrolysis, $100 \mathrm{~g}$ sample viscera were used, and the mixture was poured directly into a $300 \mathrm{ml}$ closed glass vessel with a double jacket to enable thermic exchanges (heating or cooling). Before the start of the hydrolysis reaction, an initial 15 min mixing was done for the $\mathrm{pH}$ adjustment (through the addition of $\mathrm{NaOH} 1 \mathrm{M}$ ), and the obtention of the desired temperature (using a water bath). 


\section{ACCEPTED MANUSCRIPT}

\subsection{Optimization experiments:}

Response surface methodology (RSM) was applied to optimize the hydrolysis conditions. The objective of this optimization was protein recovery in the soluble aimed at valorization for animal nutrition, particularly aquaculture feeding.

Central composite design (CCD), with 5 levels of each treatment and 4 replications at the central point was used (Table 1). The range of independent variables, enzyme activity (x1), time (x2), and temperature (x3), was adopted from preliminary experiments (data not published). The CCD in the experimental design consists of eight factorial points, six axial points, and four replicates of the central point (Table 1). Results for the degree of hydrolysis and nitrogen recovery (NR) as independent variables are shown in Table 1. Experimental runs were randomized to minimize the effects of unexpected variability in the observed responses. A quadratic polynomial regression model was assumed to predict the responses. The model proposed for the response is given in Equation 1:

$$
Y=\beta_{0}+\sum_{i=1}^{3} \beta_{i} X_{i}+\sum_{i=1}^{3} \beta_{i i} X_{i}^{2}+\sum_{i=1}^{2} \sum_{j=i+1}^{3} \beta_{i j} X_{i} X_{j}
$$

Equation 1

where $\mathrm{Y}$ is the dependent variable (degree of hydrolysis or nitrogen recovery in real value), $\beta 0$ is constant, and $\beta \mathrm{i}, \beta \mathrm{ii}$, and $\beta \mathrm{ij}$ are coefficients estimated by the model. $\mathrm{xi}, \mathrm{xj}$ are levels of the independent variables. They represent the linear, quadratic, and cross product effects of the $\mathrm{x} 1$, $\mathrm{x} 2$, and $\mathrm{x} 3$ factors on the response, respectively. The model evaluated the effect of each independent variable to a response. Analysis of the experimental design and calculation of

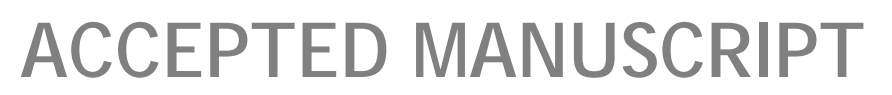




\section{ACCEPTED MANUSCRIPT}

predicted data were carried out using Design Expert software (7.0.0 trial, Stat-Ease Inc., Minneapolis, MN, USA) to estimate the response values. Subsequently, three additional confirmation experiments were conducted to verify the validity of the statistical experimental strategies. The optimized design was further validated through different random combinations of parameters to evaluate the usefulness of the design.

\subsection{Determination of $\alpha$-amino acid and degree of hydrolysis}

The determination of $\alpha$-amino acid content was conducted by the modified methods of AdlerNissen (1979) and Crowell et al. (1985). Properly diluted samples (125 $\mu \mathrm{L}$ ) were mixed with 2.0 $\mathrm{mL}$ of $0.2125 \mathrm{M}$ phosphate buffer, $\mathrm{pH}$ 8.2, followed by the addition of $1.0 \mathrm{~mL}$ of $0.01 \%$ TNBS solution. The mixtures were then placed in a water bath at $50{ }^{\circ} \mathrm{C}$ for $30 \mathrm{~min}$ in the dark. The reaction was terminated by adding $2.0 \mathrm{~mL}$ of $0.1 \mathrm{M}$ sodium sulfite. The mixtures were cooled down at ambient temperature for $15 \mathrm{~min}$. The absorbance was measured at $420 \mathrm{~nm}$, and R-amino acid was expressed in terms of L-leucine. The DH was determined using the modified method of Beak and Cadwallader (1995) and defined as follows (Equation 2):

$$
\mathrm{DH}=\left[\left(L_{t}-L_{0}\right) /\left(L_{\max }-L_{0}\right)\right] \times 100
$$

$L t$ : the amount of $\alpha$-amino acid released at time $t$

$L_{0}$ : the amount of $\alpha$-amino acid in original cuttlefish viscera

$L_{\max }$ : the maximum amount of $\alpha$-amino acid in cuttlefish viscera obtained after acid hydrolysis. Cuttlefish viscera suspension $(500 \mu \mathrm{L})$ was mixed with $4.5 \mathrm{~mL}$ of $6 \mathrm{~N} \mathrm{HCl}$. The tube with

\section{ACCEPTED MANUSCRIPT}




\section{ACCEPTED MANUSCRIPT}

sample mixtures was flashed with nitrogen gas and sealed tightly. The hydrolysis was run at 100 ${ }^{\circ} \mathrm{C}$ for $24 \mathrm{~h}$ (Beak and Cadwallader, 1995). The acid-hydrolyzed sample was filtered (Whatman paper no. 1) to remove the solid debris. The supernatant was neutralized with $6 \mathrm{~N} \mathrm{NaOH}$ before $\alpha$-amino acid determination.

\subsection{Determination of $N R$}

After achieving the hydrolysis reaction, the supernatant was obtained by centrifuging at $20000 \mathrm{~g}$ for $15 \mathrm{~min}$. The volume of soluble fraction was recorded, and total nitrogen in supernatant was determined using Kjeldahl method (AOAC, 1995). NR was calculated as follows (Equation 3):

$\mathrm{NR}(\%)=[$ total nitrogen in supernatant (mg)/total nitrogen in substrate $(\mathrm{mg})] \times 100$

Equation (3)

\subsection{Proximate composition}

Proximate analysis of the raw material and protein hydrolysate was performed for moisture, ash, and protein according to the procedures of the Association of Official Analytical Chemists (AOAC, 1995). Total fat was extracted with a mixture of chloroform and methanol by following the method of Bligh and Dyer (1959).

\subsection{Amino acid composition}

Samples for analysis of total amino acids were hydrolyzed in $6 \mathrm{M} \mathrm{HCl}$ for $18 \mathrm{~h}$ at $118{ }^{\circ} \mathrm{C}$ and

\section{ACCEPTED MANUSCRIPT}




\section{ACCEPTED MANUSCRIPT}

analyzed by gas chromatography-flame ionization detector (GC-FID) system (Perkin Elmer Autosystem XL, Waltham, MA, USA) after derivatization with the EZ: Faast kit method. The temperature of the injector was maintained at $250^{\circ} \mathrm{C}$, while the detection occurred at $320^{\circ} \mathrm{C}$. Separation was achieved using a Zebron ZB-AAA GC column (10m x $0.25 \mathrm{~mm})$ with an oven temperature linearly increasing from 110 to $320^{\circ} \mathrm{C}$ at $32^{\circ} \mathrm{C} / \mathrm{min}$.

Considering the contents of essential amino acids (EAA), the chemical score of the protein

hydrolysate was computed as per Vidotti et al. (2003) considering the EAA in the standard protein, as described by FAO/WHO (1985). In brief, the chemical score was calculated using the following equation:

Chemical score $=\frac{\text { EEA in test protein }(\mathrm{g} / \mathrm{kg})}{\text { EEA in standard protein }(\mathrm{g} / \mathrm{kg})} \quad$ Equation (4)

\subsection{Heavy metal composition of cuttlefish viscera}

The concentrations of four toxic heavy metals, arsenic (As), mercury (Hg), lead ( $\mathrm{Pb})$, and cadmium (Cd), were determined, after digestion, by the Association of Official Analytical Chemists methods. Mercury and arsenic levels were determined by hydride generation atomic absorption spectrophotometry, while cadmium and lead levels were determined by graphite tube atomic absorption spectrophotometry. Analyses were carried out in triplicate. 


\section{ACCEPTED MANUSCRIPT}

\section{Results and discussion}

\section{1. Proximate composition of the raw material and cuttlefish protein hydrolysate}

The proximate composition of the raw material and spray-dried cuttlefish protein hydrolysates is displayed in Table 2. The cuttlefish protein hydrolysates powder was of 1 black color, due to the presence of ink, with fishy odor and taste. Similar results for protein contents were reported by other authors for different fish and degree of hydrolysis (Gbogouriand et al., 2004; Kristinsson and Rasco 2000a; Sathivel et al., 2003). The cuttlefish protein hydrolysates reported a relatively low fat content. Also, enzymatic hydrolysis can release the fat from tissue and centrifugation before spray drying leads to reduction of the fat content of final cuttlefish protein hydrolysates. The protein hydrolysate had a low fat content, and a decreased fat content enhances the stability of the product (Nilsang et al., 2005).

\subsection{Heavy metal composition}

The average values of metal contents, expressed in (mu)g g- 1 wet weight were 0.117 for mercury, 0.128 for arsenic, 0.0223 for cadmium, 0.0366 for lead, and non-detectable for tin. The results of this study indicate that the cuttlefish viscera of the Gabès Gulf fishing area of Tunisia have concentrations well below the permissible FAO/WHO levels for these toxic metals. Their

contribution to the body burden can be therefore considered negligible, and the resulting cuttlefish protein hydrolysates seem to be safe when incorporated into animal feed.

\section{ACCEPTED MANUSCRIPT}




\title{
ACCEPTED MANUSCRIPT
}

\subsection{Response surface analysis}

\subsubsection{Development of response surface models}

Regression analysis was employed to fit a full response surface model for every response investigated, including all linear (X1, X2, X3) and quadratic/interaction terms (X1X2, X1X3, X2X3, X11, X22, X33). The regression coefficients for the $2^{\text {nd }}$ order response surface models in terms of coded units are shown in Table 5. The examination of the fitted model was necessary to ensure that it provided an adequate approximation to the true system. The significant coefficients $(\mathrm{P}<0.05)$ were used to develop the models (Table 5). The regression models made to predict degree of hydrolysis and nitrogen recovery for actual variables are presented in Equations 5 and 6.

\author{
$\mathrm{DH}=-51.90251+(+2.740546)$ Temperature $+(+0.42929) \mathrm{Time}+(+64.12926) \mathrm{E} / \mathrm{S}+$ \\ $(-5.3061 \mathrm{E}-003)$ Temperature $\times$ Time $+(+0.078)$ Temperature $\times \mathrm{E} / \mathrm{S}+(-0.0238)$ Time $\times \mathrm{E} / \mathrm{S}+(-$ \\ 0.02268) Temperature ${ }^{2}+(-6.42113 \mathrm{E}-004)$ Time $^{2}+(-618.86623) \mathrm{E} / \mathrm{S}^{2}$
}

Equation (5)

Nitrogen Recovery $=-20.0028+(+1.268)$ Temperature $+(+1.4417)$ Time $+(+482$.

09412) $\mathrm{E} / \mathrm{S}+(-0.11015)$ Temperature $\times$ Time $+(-0.39541)$ Temperature $\times \mathrm{E} / \mathrm{S}+(+0.38010)$

Time $\times$ E/S $+(-0.13515)$ Temperature2 + (-5.17878E-003) Time $2+(-4253.31259)$ E/S2

Equation (6)

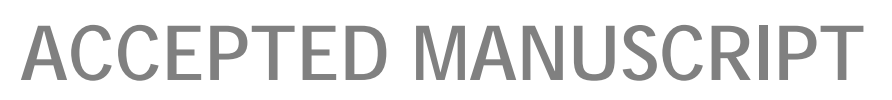




\section{ACCEPTED MANUSCRIPT}

The results of the analysis of variance (ANOVA) for DH and NR in Tables 3 and 4 demonstrate that the statistical model is significant at a $99.999 \%$ confidence level $(\mathrm{p}<0.0001)$. As can be seen from the ANOVA tables (Tables 3 and 4), among the independent variables the temperature and time had a relatively higher significant effect $(\mathrm{p} \leq 0.01)$ as compared to the enzyme activity $(p \leq 0.05)$. The interactions between the different factors did not significantly influence ( $p>0.05)$ the response variable, except the interaction between time and temperature $(\mathrm{p} \leq 0.01)$.

The total determination coefficient, $\mathrm{R}^{2}=0.955$ and 0.972 for $\mathrm{DH}$ and NR, respectively, implies that the regression models explained the reaction well. Adjusted $\mathrm{R}^{2}$ was 0.917 and 0.953 for DH and NR, respectively, which indicates that the model explains $91 \%$ and $96 \%$ of the variation in the data, and that the experiment error was very small. The value of Predicted $R^{2}$ ( 0.768 and 0.922) was close to that of Adjusted $\mathrm{R}^{2}$. The model was considered adequate with adequate precision value that measures the signal to noise ratio. A ratio greater than 4 is desirable (Canettieri et al., 2007); this value for DH and NR was 16.25. As the test of lack of fit hypothesis was not significant $(\mathrm{p}>0.05)$ in the model, the model was fitted to the data. A good fit means that the generated models adequately explained the data variation and significantly represented the actual relationships between the reaction parameters. These results agreed with nitrogen recovery

that had significant model at a $99.999 \%$ confidence level $(\mathrm{p}<0.0001), \mathrm{R}^{2}=0.972$, adequate precision of 21.6, and lack of fit at 0.841 .

\section{ACCEPTED MANUSCRIPT}




\section{ACCEPTED MANUSCRIPT}

\subsubsection{Interpretation of residual graphs}

The normal probability plot, Figures 1a and 1c, shows that the distribution of residual values, which is defined as the difference between the predicted (model) and observed (experimental), forms a straight line, and residual values are normally distributed on both sides of the line indicating that the experimental points are reasonably aligned with the predicted value. In further analysis, each of the observed values for the degree of hydrolysis was compared with the adequate predicted value. The parity plot (Figures $1 \mathrm{~b}$ and $1 \mathrm{~d}$ ), displaying the predicted values as function of the actual values, shows an acceptable level of agreement. All these results imply a satisfactory mathematical description of the hydrolysis process by the fitted model.

\subsubsection{Optimization of multiple responses}

Response surface methodology has been used successfully to optimize the parameters influencing the protein hydrolysis (Cheison et al., 2007; Nilsang et al., 2005). RSM is a statistical technique for designing experiments, building models, evaluating the effects of several factors, and searching optimum conditions for desirable responses. The 3D response surfaces when one of the variables is fixed at the central point and the other two are allowed to vary are shown in Figure 2. The maximum predicted value is indicated by the surface confined in the smallest ellipse in the contour diagram. Elliptical contours are obtained when there is a perfect interaction between the independent variables (Muralidhar et al., 2001).

As shown in Figure 2, if the selected variable's value was in the optimum range, the DH increased until combination of the time, temperature, and E/S ratio reached a maximum yield of

\section{ACCEPTED MANUSCRIPT}




\section{ACCEPTED MANUSCRIPT}

the product. But if the conditions that selected for the hydrolyzation were out of this range, even though it has higher value for each of the variables, the $\mathrm{DH}$ can not reach the high value, and it will stay at the lower point of DH. This confirmed that time and temperature affected the enzyme hydrolysis activity.

The shape of the hydrolysis curve has been associated with enzyme inactivation, product inhibition by hydrolysis products formed at high degrees of hydrolysis, a low Km value for the soluble peptides that act as effective substrate competitors to the unhydrolyzed protein, and possibly auto digestion of the enzyme (Rebeca et al., 1991; Mullally et al., 1995). Surowka and Fik (1992), who measured the production of protein hydrolysate with Neutrase from chicken heads, reported that hydrolysis increased as substrate concentration decreased. Also, Baek and Cadwallader (1995), who used Optimize to hydrolyze crayfish processing byproducts, reported that the \%DH increased as substrate concentration decreased to $45 \%(\mathrm{w} / \mathrm{v})$, suggesting that high \%DH did not coincide with a high amount of hydrolysates. Similarly, Moreno and Cuadrado (1993) hydrolyzed vegetable proteins with Alcalase® and found reaction mechanism consistent with substrate inhibition and a second-order deactivation with respect to the enzyme concentration. These results confirm that for production of a protein hydrolysate, different conditions must be noticed and all of the conditions are related. Different conditions such as time, temperature, substrate, and enzyme concentration, have an optimum range for production of protein hydrolysate with high DH and NR.

The response surface graph for $\mathrm{DH}$ of protein hydrolysate as a function of temperature and time in hydrolysis at an enzyme to substrate level of $0.07 \mathrm{AU} / \mathrm{g}$ protein indicates that the $\mathrm{DH}$ is very

\section{ACCEPTED MANUSCRIPT}




\section{ACCEPTED MANUSCRIPT}

dependent on the time and temperature of hydrolyzation and that with increase of time, high DH can be achieved at lower temperatures. Also, DH increases with an increase in time when the enzyme/substrate ratio ranges between $0.05-0.09 \mathrm{AU} / \mathrm{g}$ protein and at fixed temperature of $50^{\circ} \mathrm{C}$. In terms of temperature, a range between $48^{\circ} \mathrm{C}$ to $55^{\circ} \mathrm{C}$ in this model produced a high $\mathrm{DH}$. An E/S ratio ranging between $0.05-0.09 \mathrm{AU} / \mathrm{g}$ protein was desirable to promote the $\mathrm{DH}$, but a continued increase in enzyme concentration did not result in improved DH. We also get this result for nitrogen recovery which showed that DH and NR are related, and a higher DH can lead to achieving a higher nitrogen recovery. In previous studies, Bhaskar et al. (2008) found that the optimum conditions for hydrolyzing Indian carp (Catla catla) visceral waste proteins hydrolyzing at $50 \% \mathrm{DH}$ were 135 minutes, $55^{\circ} \mathrm{C}$, and enzyme concentration of $11 \mathrm{AU} / \mathrm{l}$ protein extract at the $\mathrm{pH}$ of 8.5. Benjakul and Morrisey (1997) estimated different conditions for hydrolyzing protein waste materials acquired from processing Pacific whiting (Merluccius productus) but by lowering the levels of hydrolysis. Further, it is well-known that the peptide chain length and the DH depend upon the extent of hydrolysis, conditions of hydrolysis, enzyme concentration, and type of the substrate proteins (Kristinsson and Rasco, 2000a). Hence, the optimum conditions for hydrolyzing different substrates will be different and vary depending upon the substrate used.

\subsubsection{Optimization and model validation}

The DH has been used as an indicator for the cleavage of peptide bond, whereas NR reflects the yield that can be recovered, the soluble phase, from the hydrolysis process. In order to obtain the maximum nitrogen recovery and degree of hydrolysis of the hydrolysates, the optimization of the

\section{ACCEPTED MANUSCRIPT}




\section{ACCEPTED MANUSCRIPT}

model was performed by setting the maximum value (Y1 and Y2) as the goal and, for cost effective reasons, restrict the software to use minimum E/S ratio and temperature. The resulting maximum values of $\mathrm{NR}$ and $\mathrm{DH}$ of $90.31 \%$ and $20.14 \%$, respectively, were obtained with the following conditions: E/S ratio (X1): 0.04 AU/g protein, time (X2): 85.01 minute, and temperature (X3): $45.60^{\circ} \mathrm{C}$.

To confirm the validity of the model, three assays were performed under the optimal conditions given above. The experimental values for $\mathrm{DH}$ and nitrogen recovery were $21.96 \pm 0.3 \%$ and $90.11 \pm 1.03 \%$, respectively. The experimental values agreed with the value predicted by the model within a 95\% confidence interval. The above results confirmed that the model was powerful and suitable for the estimation for experimental values.

Our results showed that NR was directly proportional to $\mathrm{DH}$. The correlation coefficients indicated that a close relationship existed between DH and NR. Similar results were reported by many authors working on enzymatic hydrolysis of marine organisms. Shahidi et al. (1995) reported that the rate of hydrolysis and nitrogen recovery followed the same evolution way. Also, Beak and Cadwallader (1995) presented the same results about the correlation between DH and NR after their study on crayfish processing by-product hydrolysate treated with Alcalase. Early work by Cheftel et al. (1971) on fish protein concentrate showed that an increase in DH is expressive of a positive effect on overall proteolysis, with subsequent increases in solubilization of protein. 


\section{ACCEPTED MANUSCRIPT}

\subsection{Amino acid composition of the hydrolysate prepared using Pepsin}

The nutritional value of food depends on the type and amount of amino acids available for body functions. The spray-dried fish protein hydrolysate was a yellow powder, of which amino acid composition is presented in Table 6. Chemical score has been used to evaluate the nutritive value of a protein. This parameter compares the levels of essential amino acids among the test and standard proteins (Sgarbieri, 1987). In the current study, the chemical scores were computed based on the reference protein of FAO/WHO (1985) and NRC (1993). Based on this study, leucine was the most abundant amino acid, measuring $70.8 \mathrm{~g} / \mathrm{kg}$. The chemical scores computed indicate that methionine and histidine were the most limiting amino acids as compared to both reference proteins, followed by phenylalanine + tyrosine as compared to reference protein of NRC (1993) and isoleucine in reference to the FAO/WHO (1985) standard. All other amino acids are present in a sufficient quantity as required based on standard references. In nonessential quantified amino acids, the highest concentration in the dry powder was glycine, measuring $150.5 \mathrm{~g} / \mathrm{kg}$. The current study used whole fish for FPH production, and the high content of glycine may be due to the skin of fish which has high collagen content. Collagen has high content of glycine. The amino acid in lower concentrations in the hydrolysate was aspartic acid.

Also due to the high temperatures that the hydrolysate was subjected to in the process of spray drying, loss of a portion of the amino acids may take place (Abdul-Hamid et al., 2002). The amino acid composition indicates that cuttlefish protein hydrolysate can be used in fish diets.

\section{ACCEPTED MANUSCRIPT}




\section{ACCEPTED MANUSCRIPT}

\section{Conclusions}

Hydrolysis of common cuttlefish Sepia officinalis using Pepsin resulted in 21.96\% DH and 90.11\% NR. The DH and NR is influenced significantly by the enzyme concentration, time, and temperature that are applied for the hydrolysis. The optimum hydrolysis conditions using Pepsin included an $\mathrm{E} / \mathrm{S}$ ratio of $0.04 \mathrm{AU} / \mathrm{g}$ protein, 85 minutes as hydrolysis time, and $45^{\circ} \mathrm{C}$ for the temperature. The hydrolysate prepared from cuttlefish has a good amino acid composition and hence has the potential to be an ingredient in balanced fish diets and in additives in the food industry.

\section{References}

Abdul-Hamid, A., Bakar, J., and Bee G.H. 2002. Nutritional quality of spray dried protein hydrolysate from black tilapia (Oreochromis mossmbicus). Food Chem. 78: 69-74.

Adler-Nissen, J. 1984. Control of the proteolytic reaction and of the level of bitterness in protein hydrolysis process. J. Chem. Tech. Biotech. 34B: 215 - 2422.

AOAC. 1995. Official methods of analysis.16th ed. Washington, DC: Association of Official Analytical Chemists, Inc.

Beak, H.H., and Cadwallader, K.R. 1995. Enzymatic hydrolysis of crayfish processing byproducts. J. Food Sci. 60: 929-935.

Benjakul, B., Morrissey, M.T. 1997. Protein hydrolysates from Pacific whiting solid wastes. J. Agri. Food Chem. 45: 3424. 


\section{ACCEPTED MANUSCRIPT}

Bhaskar, N., Modi, V.K., Govindaraju, K., Radha, C., and Lalitha, R.G. 2007. Utilization of meat industry by-products: protein hydrolysate from sheep visceral mass. Biores. Tech. 98: 388394.

Bhaskar, N., Benila, T., Radha, C., and Lalitha, R.G. 2008. Optimization of enzymatic hydrolysis of visceral waste proteins of Catla (Catla catla) for preparing protein hydrolysate using a commercial protease. Biores. Tech. 99 (10): 4105.

Bligh, E.G., and Dyer, W.J. 1959. A rapid method of total lipid extraction and purification. Can. J. Biochem. Physiol. 37(8): 911-917.

Canettieri, E. V., Rocha, G. J., Carvalho, J. A., and Silva, J. B. 2007. Optimization of acid hydrolysis from the hemicellulosic fraction of Eucalyptus grandis residue using response surface methodology. Biores. Tech. 98(2): 422-428.

Cheison, S.C., Wang, Z., and Xu, S.Y. 2007. Use of response surface methodology to optimize the hydrolysis of whey protein isolate in a tangential flow filter membrane reactor. J. Food Eng. 80: 1134-1145.

Cheftel, C. C., Ahern, M.,Wang, D. I. C., and Tannenbaum, S. R. 1971. Enzymatic solubilization of fish protein concentrate: Batch studies applicable to continuous enzyme recycling processes. J. Agric. Food Chem. 19: 155-161.

Dumay, J., Donnay-Moreno, C., Barnathan, G., Jaouen, P., and Berge, J. P. 2006. Improvement of lipid and phospholipid recoveries from sardine (Sardina pilchardus) viscera using industrial proteases. Process Biochem. 41: 2327-2332. 


\section{ACCEPTED MANUSCRIPT}

Espe, M., Raa, J., and Njaa, L.R. 1989. Nutritional value of stored fish silage as protein source of young rats. J. Sci. Food Agri. 49: 259-270.

FAO/WHO. 1985. Energy and protein requirements. Report of Joint FAO/WHO/UNU Expert Consultation Technical Report. FAO/WHO and United Nations University, Geneva, Series No. 724, pp. 116-129.

Flynn, K.J. 1988. Some practical aspects of measurements of dissolved free amino acids in natural waters and within microalgae by the use of HPLC. Chem. Ecol. 3: 269-93.

Gbogouri, G.A., Linder, M., Fanni, J., and Parmentier, M. 2004. Influence of hydrolysis degree on the functional properties of salmon byproducts hydrolysates. J. Food Sci. 69: 615-622.

Guerard, F., Duffose, L., De La Broise, D., and Binet, A. 2001. Enzymatic hydrolysis of proteins from yellowfin tuna (Thunnus albacares) wastes using Alcalase®. J. Mol. Catalysis B: Enzymatic. 11: 1051-1059.

Hoyle, N.T., and Merritt, J.H. 1994. Quality of fish protein hydrolysate from Herring (Clupea harengus). J. Food Sci. 59 (76-79): 129.

Je, J.Y., Park, P.J., and Kim, S.K. 2004. Antioxidant activity of a peptide isolated from Alaska pollack (Theragra chalcogramma) frame protein hydrolysate. Food Res. Int. 38(1): 45-50.

Kim, S.K., Kim, Y.T., Byun, K.S., Joo, D.S., and Shahidi, F. 2001. Isolation and characterization of antioxidative peptides from gelatine hydrolysate of Alaska Pollack skin. J. Agri. Food Chem. 49: 1984-1989.

\section{ACCEPTED MANUSCRIPT}




\section{ACCEPTED MANUSCRIPT}

Kim, S. K., and Lee, E.H. 1987. Enzymatic modification of sardine protein concentrate. Agri. Chem. Biotech. 30: 234-241.

Kristinsson, H.G., and Rasco, B.A. 2000a. Biochemical and functional properties of Atlantic salmon (Salmo salar) muscle hydrolyzed with various alkaline proteases. J. Agri. Food Chem. 48: 657-666.

Kristinsson, H.G., and Rasco, B.A. 2000b. Fish protein hydrolysates: Production, biochemical and functional properties. Crit. Rev. Food Sci. Nutr. 40(1): 43-81.

Liaset, B., Lied, E., and Espe, M. 2000. Enzymatic hydrolysis of by-products from the fish

filleting industry; chemical characterization and nutritional evaluation. J. Sci. Food Agri. 80: 581-589.

Liaset, B., Nortvedt, R., Lied, E., and Espe, M. 2002. Studies on the nitrogen recovery in enzymatic hydrolysis of Atlantic salmon (Salmo salar, L.) frames by protamexTM protease. Proc. Biochem. 37: 1263- 1269.

Lindroth, P., and Mopper, K. 1979. High performance liquid chromatographic determination of subpicomole amounts of amino acids by precolumn fluorescence derivatization with ophthaldialdehyde. Anal. Chem. 51: 1667-74.

Moreno, M.M.C., and Cuadrado, V.F. 1993. Enzymic hydrolysis of vegetable proteins: mechanism and kinetics. Process Biochem. 28: 481-490. 


\section{ACCEPTED MANUSCRIPT}

Mullally, M.M., O’Callaghan, D.M., FitzGerald, R.J., Donnelly, W.J., and Dalton, J.P. 1995. Zymogen activation in pancreatic endoproteolytic preparations and influence on some whey protein characteristics. J. Food Sci. 60: 227-233.

Muralidhar, R.V., Chirumamila, R.R., Marchant, R., and Nigam, P. 2001. A response surface approach for the comparison of lipase production by Candida cylindracea using two different carbon sources. Biochem. Eng. J. 9: 17-23.

Nilsang, S., Lertsiri, S., Suphantharika, M., and Assavanig, A. 2005. Optimization of enzymatic hydrolysis of fish soluble concentrate by commercial proteases. J. Food Eng. 70: 571-578.

NRC. 1993. National Research Council - nutrient requirements of Fish. National Academy of Sciences, Washington, 124p.

Otani, L., Ninomiya, T., Murakami, M., Osajima, K., Kato, H. and Murakami, T. 2009. Sardine peptide with angiotensin I-converting enzyme inhibitory activity improves glucose tolerance in storke prone spontaneously hypertensive rats. Biosci. Biotech. Biochem. 73: 2203- 2209.

Ovissipour, M., Abedian, A., Motamedzadegan, A., Rasco, B., Safari, R., and Shahiri, H. 2009. The effect of enzymatic hydrolysis time and temperature on the properties of protein hydrolysates from Persian sturgeon (Acipenser persicus) viscera. Food Chem. 115: 238-242.

Quaglia, G. B., and Orban, E. 1990. Influence of enzymatic hydrolysis on structure and emulsifying properties of sardine (Sardina pilchardus) protein hydrolysates. J. Food Sci. 55: 1571-1573.

\section{ACCEPTED MANUSCRIPT}




\section{ACCEPTED MANUSCRIPT}

Rajapakse, N., Mendis, E., Byun, H. G., and Kim, S. K. 2005. Purification and in vitro antioxidative effects of giant squid muscle peptides on free radical-mediated oxidative systems. $\mathrm{J}$ Nutr Biochem. 16(9): 562-9.

Ravallec-Ple', R., Charlot, C., Pires, C., Braga, V., Batista, I., Wormhoudt, A.V., Le Gal, Y. M. and Fouchereau-Pe', R. 2001. The presence of bioactive peptides in hydrolysates prepared from processing waste of sardine (Sardina pilchardus). J. Sci. Food Agri. 81: 1120-1125.

Rebeca, B.D., Pena-Vera, M.T., and Diaz-Castaneda, M. 1991. Production of fish protein hydrolysates with bacterial proteases; Yield and nutritional value. J. Food Sci. 56: 309-314.

Sathivel, S., Bechtel, P.J., Babbitt, J., Smiley, S., Crapo, C., Reppond, K.D., and Prinyawiwatkul, W. 2003. Biochemical and functional properties of herring (Clupea harengus) byproduct hydrolysates. J. Food Sci. 68: 2196-2200.

Sgarbieri, V.C. 1987. Alimentacao e Nutricao: Fator de saude edesenvolvimento. UNICAMP, Campinas, Brazil.

Shahidi, F., and Amarowicz, R. 1996. Antioxidant activity of protein hydrolysates from aquatic species. JAOCS. 73: 1197-9.

Shuler, P. 1990. Natural antioxidants exploited commercially. In: Hudson B, editor. Food antioxidants. New York: Elsevier Applied Science p. 99-170.

Surówka, K., and Fik, M. 1992. Studies on the recovery of proteinaceous substances from chicken heads. I. An application of neutrase to the production of protein hydrolysate. Int. J. Food Sci. Tech. 27: 9-20. 


\section{ACCEPTED MANUSCRIPT}

Vidotti, R.M., Viegas, E.M.M., and Careiro, D.J. 2003. Amino acid composition of processed fish silage using different raw materials. Anim. Feed Sci. Tech. 105: 199-204.

Viera, G.H.F., Martin, A.M., Sampaiao, S.S., Omar, S., and Gonsalves, R.C.F. 1995. Studies on the enzymatic hydrolysis of Brazilian lobster (Panulirus spp.) processing wastes. J. Sci. Food Agri. 69: 61-65.

Zhang, W., and Takeshi, S. 1994. Manufacture and characterization of an active protein hydrolysate from sardine muscle. Memoirs of the College of Agriculture Ehime University. 38: 319-332. 


\section{ACCEPTED MANUSCRIPT}

Fig.1. Relationship between the observed and predicted values of the nitrogen recovery (Parity plot) ( $a$ and b) and the degree of hydrolysis (c and d).
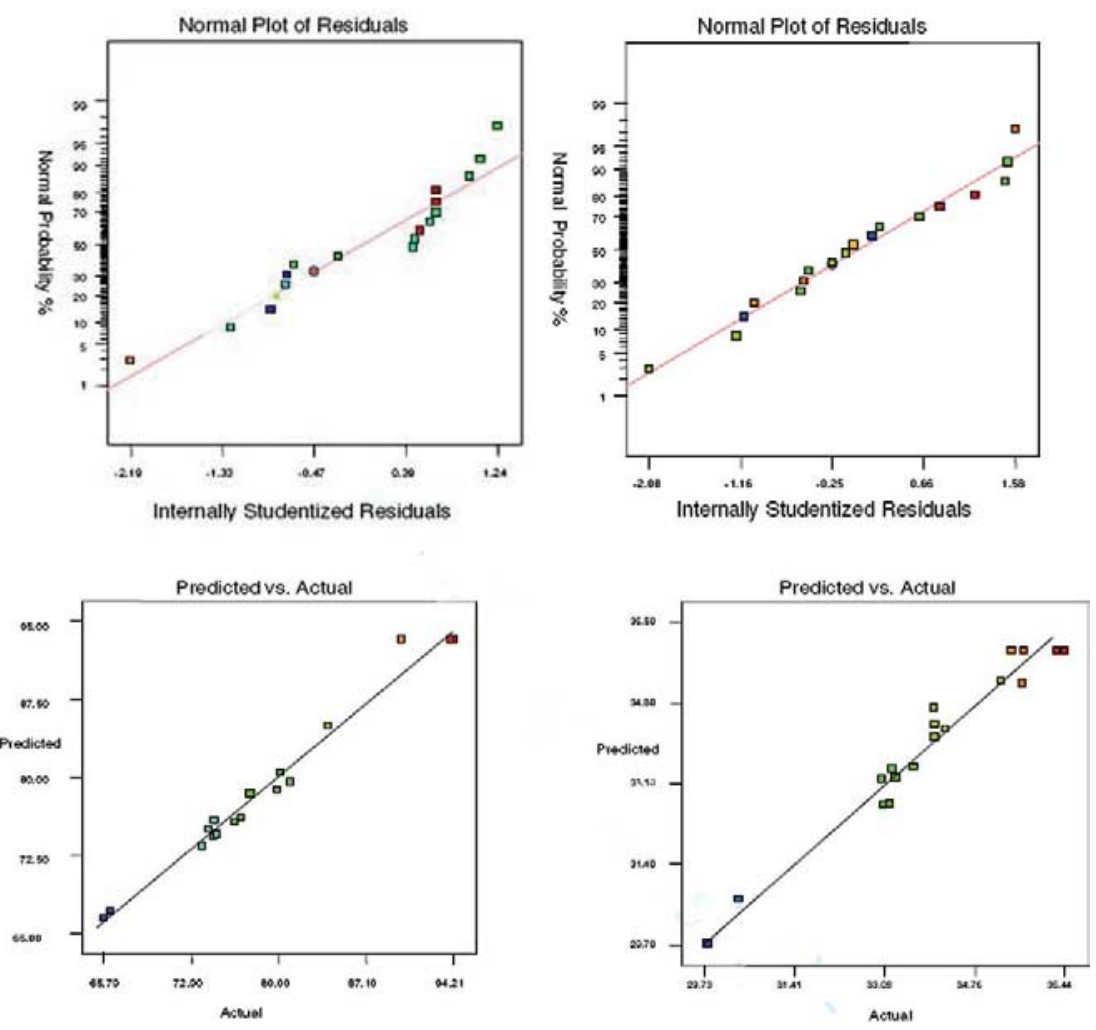


\section{ACCEPTED MANUSCRIPT}

Fig.2. 3D response surface graph for degree of hydrolysis and nitrogen recovery as a function of time, temperature, and enzyme / substrate ratio during hydrolysis of cuttlefish Sepia officinalis with Pepsin.
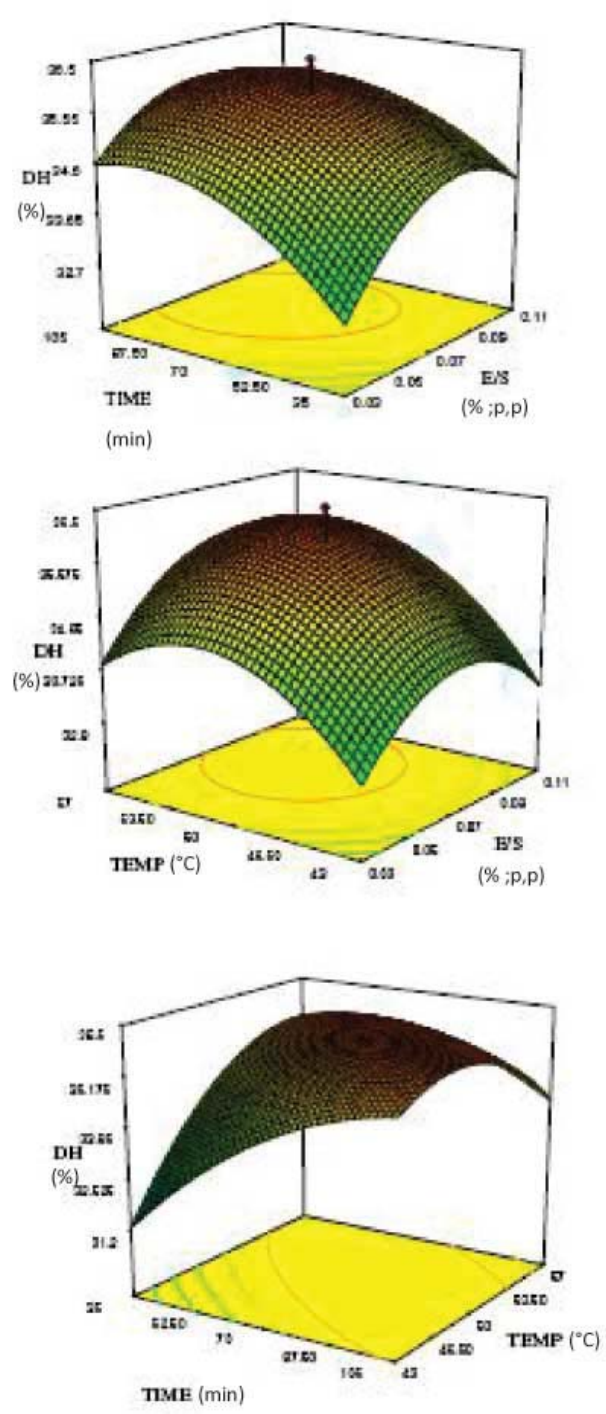
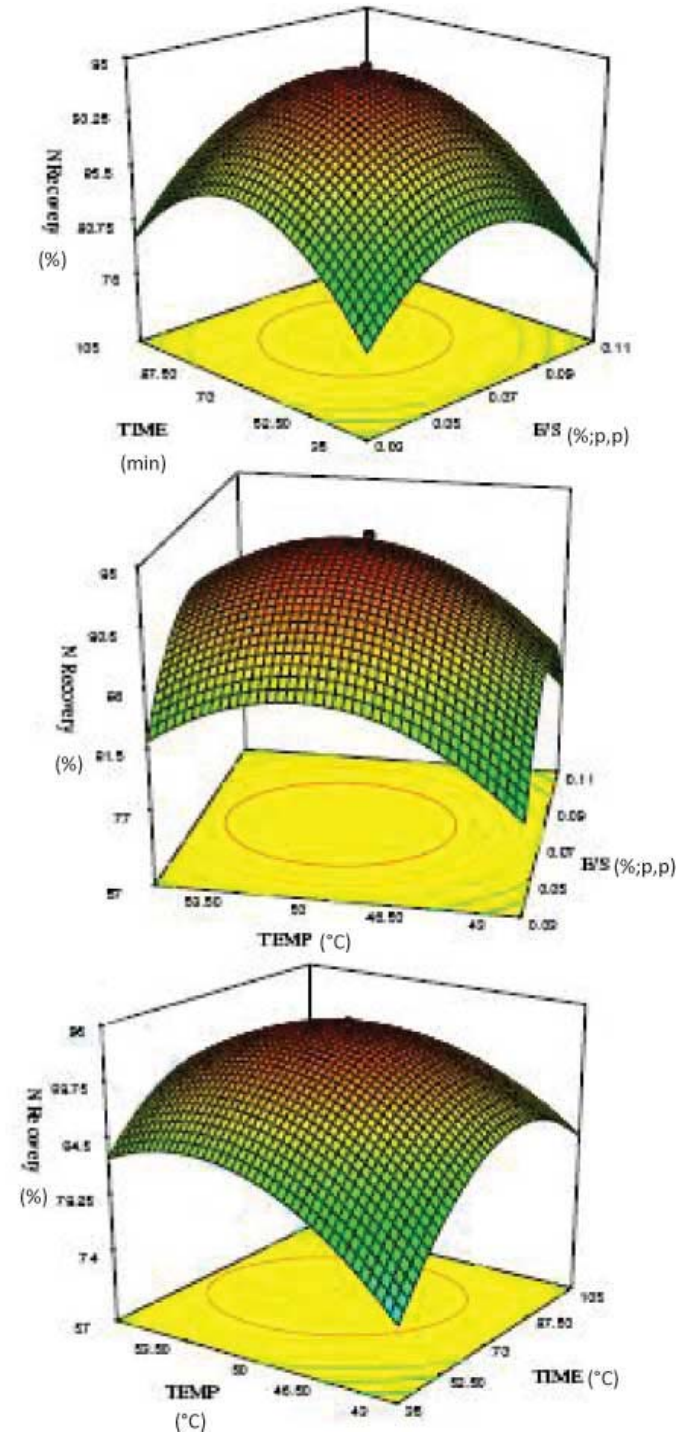


\section{ACCEPTED MANUSCRIPT}

Table 1

Experimental design used in RSM studies by using three independent variables with four center points showing observed degree of hydrolysis and nitrogen recovery

Run $\mathrm{N}^{\circ}$ Coded Levels of Variable $\quad$ DH (\%) NR (\%)

Enzyme Hydrolysis Time

Concentration (min)

Temperature $\left({ }^{\circ} \mathrm{C}\right)$

$(\mathrm{AU} / \mathrm{g}) \mathrm{X}_{1} \quad \mathrm{X}_{2}$

$\mathrm{X}_{3}$

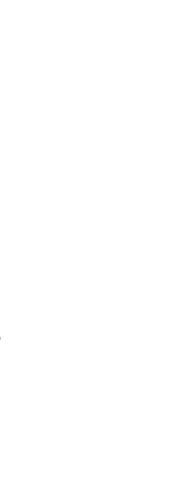

$-1$

$19.77 \quad 66.33$

2

1

$-1$

$-1$

$20.36 \quad 65.45$

3

$-1$

1

$-1$

$24.02 \quad 74.76$

4

1

1

$-1$

$24.02 \quad 74.88$

5

$-1$

$-1$

1

$23.62 \quad 76.98$

6

1

$-1$

1

$25.60 \quad 74.33$ 


\section{ACCEPTED MANUSCRIPT}

\begin{tabular}{|c|c|c|c|c|c|}
\hline 7 & -1 & 1 & 1 & 23.02 & 75.36 \\
\hline 8 & 1 & 1 & 1 & 23.27 & 77.69 \\
\hline 9 & $-\alpha$ & 0 & 0 & 23.03 & 79.90 \\
\hline 10 & $\alpha$ & 0 & 0 & 24.56 & 76.45 \\
\hline 11 & 0 & $-\alpha$ & 0 & 23.22 & 80.17 \\
\hline 12 & 0 & $\alpha$ & 0 & 23.25 & 80.95 \\
\hline 13 & 0 & 0 & $-\alpha$ & 23.18 & 84.02 \\
\hline 14 & 0 & 0 & $\alpha$ & 23.99 & 90.01 \\
\hline 15 & 0 & 0 & 0 & 26.28 & 90.52 \\
\hline 16 & 0 & 0 & 0 & 26.44 & 94.21 \\
\hline 17 & 0 & 0 & 0 & 25.67 & 94.21 \\
\hline
\end{tabular}




\section{ACCEPTED MANUSCRIPT}

18

0

0

0

25.45

93.89

$\mathrm{DH}$, degree of hydrolysis; NR, nitrogen recovery 


\section{ACCEPTED MANUSCRIPT}

Table2

Proximate composition $(\mathrm{g} / \mathrm{kg})$ of the cuttlefish and the resultant protein hydrolysate $(\mathrm{n}=3)$

\begin{tabular}{|c|c|c|c|c|}
\hline & Moisture & Ash & Total lipids & Proteins \\
\hline Cuttlefish viscera & $74.99 \pm 0.1 \%$ & $1.95 \pm 0.0 \%$ & $4.78 \pm 0.7 \%$ & $15.45 \pm 0.25 \%$ \\
\hline
\end{tabular}




\section{ACCEPTED MANUSCRIPT}

Table 3

ANOVA results of degree of hydrolysis as affected by enzyme/substrate ratio, time, and temperature during optimization experiments using Pepsin

\begin{tabular}{|c|c|c|c|c|c|}
\hline Factors & SS & $\mathrm{df}$ & MS & $\mathrm{F}$ & $\mathrm{p}$ \\
\hline Model & 53.07 & 9 & 5.90 & 22.66 & 0.0001 \\
\hline \multicolumn{6}{|l|}{ Independent } \\
\hline \multicolumn{6}{|l|}{ Variables } \\
\hline E/S Ratio $\left(\mathrm{X}_{1}\right)$ & 1070 & 1 & 1.70 & 6.55 & 0.0337 \\
\hline Time $\mathrm{X}_{2}$ & 5.14 & 1 & 5.14 & 19.74 & 0.0022 \\
\hline Temperature $\mathrm{X}_{3}$ & 6.11 & 1 & 6.11 & 23.50 & 0.0013 \\
\hline \multicolumn{6}{|l|}{ Interaction } \\
\hline $\mathrm{X}_{1} \mathrm{x} \mathrm{X}_{2}$ & 0.71 & 1 & 0.71 & 2.72 & 0.1376 \\
\hline $\mathrm{X}_{1} \times \mathrm{X}_{3}$ & 0.34 & 1 & 14.69 & 56.46 & 0.0001 \\
\hline $\mathrm{X}_{2} \times \mathrm{X}_{3}$ & 14.69 & 1 & 14.69 & 56.45 & 0.0001 \\
\hline
\end{tabular}




\section{ACCEPTED MANUSCRIPT}

\begin{tabular}{lccccc}
$\mathrm{X}_{1}^{2}$ & 9.56 & 1 & 9.56 & 36.63 & 0.0003 \\
$\mathrm{X}_{2}{ }^{2}$ & 4.95 & 1 & 4.95 & 19.03 & 0.0024 \\
$\mathrm{X}_{3}^{2}$ & 9.88 & 1 & 9.88 & 37.99 & 0.0003 \\
& & & & & \\
Lack of fit & 1.40 & 5 & 0.28 & 1.24 & 0.4567 \\
& & & & & \\
Pure Error & 0.68 & 3 & 0.23 & & \\
& & & & & \\
Corrected Total & 55.17 & 17 & & & \\
\hline P, Level of significance & & & & &
\end{tabular}




\section{ACCEPTED MANUSCRIPT}

Table 4

ANOVA results of nitrogen recovery as affected by enzyme/substrate ratio, time, and temperature during optimization experiments using Pepsin.

\begin{tabular}{|c|c|c|c|c|c|}
\hline Factors & SS & $\mathrm{df}$ & MS & $\mathrm{F}$ & $\mathrm{p}$ \\
\hline Model & 1258.72 & 9 & 139.86 & 50.49 & 0.0001 \\
\hline \multicolumn{6}{|l|}{ Independent } \\
\hline \multicolumn{6}{|l|}{ Variables } \\
\hline E/S Ratio $\left(\mathrm{X}_{1}\right)$ & 0.13 & 1 & 0.12 & 0.046 & 0.8612 \\
\hline Time $X_{2}$ & 33.56 & 1 & 33.64 & 12.14 & 0.8345 \\
\hline Temperature $\mathrm{X}_{3}$ & 43.47 & 1 & 43.47 & 15.69 & 0.0042 \\
\hline
\end{tabular}

Interaction
$\mathrm{X}_{1} \mathrm{X} \mathrm{X}_{2}$
2.50
1
2.50
0.80
0.3702
$\mathrm{X}_{1} \times \mathrm{X}_{3}$
0.11
1
0.11
0.039
0.0845 


\section{ACCEPTED MANUSCRIPT}

\begin{tabular}{|c|c|c|c|c|c|}
\hline $\mathrm{X}_{2} \times \mathrm{X}_{3}$ & 49.55 & 1 & 49.55 & 17.89 & 0.0029 \\
\hline $\mathrm{X}_{1}^{2}$ & 427.24 & 1 & 427.95 & 154.95 & 0.0001 \\
\hline $\mathrm{X}_{2}{ }^{2}$ & 458.95 & 1 & 458.95 & 165.38 & 0.0001 \\
\hline $\mathrm{X}_{3}^{2}$ & 241.88 & 1 & 241.88 & 87.99 & 0.0001 \\
\hline Lack of fit & 9.37 & 5 & 01.87 & 0.44 & 0.8567 \\
\hline Pure Error & 12.78 & 3 & 4.23 & & \\
\hline
\end{tabular}

Corrected Total $\quad 1250.17 \quad 17$

P, Level of significance 


\section{ACCEPTED MANUSCRIPT}

Table 5

Model coefficients estimated by multiple linear regression for the nitrogen recovery and degree of hydrolysis

\begin{tabular}{lll}
\hline Factors & Coefficient & \\
& & \\
& NR & DH \\
& & \\
\hline Intercept & $93.22^{* * *}$ & $20.91^{* * *}$ \\
Linear & & \\
& & \\
E/S Ratio $\left(\mathrm{X}_{1}\right)$ & 0.10 & $0.38^{*}$ \\
& & $0.62^{* *}$ \\
Time X & & \\
Temperature $\mathrm{X}_{3}$ & $1.8^{* *}$ & $0.72^{* *}$
\end{tabular}

Quadratic

E/S Ratio $\left(\mathrm{X}_{1}\right) \quad$ 0.65*** $\quad-1.08 * * *$

Time $\mathrm{X}_{2} \quad-0.13 * * * \quad-0.65 * * *$ 


\section{ACCEPTED MANUSCRIPT}

\begin{tabular}{lll} 
Temperature & $-2.49^{* * *}$ & $-1.12^{* * *}$ \\
Interaction & & \\
& & \\
$\mathrm{X}_{1} \mathrm{X} \mathrm{X}_{2}$ & -7.23 & -0.3 \\
$\mathrm{X}_{1} \mathrm{X}_{3}$ & -7.57 & 0.21 \\
& & \\
$\mathrm{X}_{2} \mathrm{X}_{3}$ & $-5.40^{* *}$ & $-1.36^{* * *}$ \\
& & \\
\hline
\end{tabular}

NR, nitrogen recovery; DH, degree of hydrolysis

* $\mathrm{p}<0.05$

$$
\begin{aligned}
& * * \mathrm{p}<0.01 \\
& * * * \mathrm{p}<0.001
\end{aligned}
$$




\section{ACCEPTED MANUSCRIPT}

Table 6

Amino acid composition of the protein hydrolysate and its chemical score in comparison with FAO/WHO reference protein

Amino Acid Quantity (g/kg) Chemical Score

\begin{tabular}{|c|c|c|c|c|c|}
\hline & $\begin{array}{l}\text { Protein } \\
\text { hydrolysate }\end{array}$ & $\begin{array}{l}\text { Reference } \\
\text { protein }^{\mathrm{a}}\end{array}$ & $\begin{array}{l}\text { Reference } \\
\text { protein }^{\mathrm{b}}\end{array}$ & $\mathrm{RP}_{1}$ & $\mathrm{RP}_{2}$ \\
\hline \multicolumn{6}{|l|}{ Essential } \\
\hline \multicolumn{6}{|l|}{ Amino Acids } \\
\hline Histidine & 14 & 20 & 21 & 0.7 & 0.67 \\
\hline Isoleucine & 33.1 & 40 & 25 & 0.38 & 1.32 \\
\hline Leucine & 72.5 & 70 & 33 & 1.47 & 2.2 \\
\hline Lysine & 56.9 & 55 & 56 & 1.03 & 0.99 \\
\hline Methionine & 24 & 35 & 32 & 0.68 & 0.75 \\
\hline Phenylalanine & 50.8 & $42.9 c$ & 65 & 3.04 & 0.78 \\
\hline
\end{tabular}




\section{ACCEPTED MANUSCRIPT}

$\begin{array}{lccccc}\text { Tyrosine } & 80 & - & - & - & - \\ \text { Threonine } & 70 & 40 & 39 & 1.75 & 1.79 \\ \text { Arginine } & 58.2 & 50 & 13.1 & 1.17 & 4.46 \\ & & & & & \\ \text { Valine } & 54.9 & 54.2 & 36 & 1.01 & 1.52 \\ & & & & & \\ \text { Non Essential } & & & & & \\ \text { Amino Acids } & & & & \end{array}$

Aspartic Acid 19

Glutamic $\quad 48.3$

Acid

Serine $\quad 33.8$

Glycine $\quad 160.5$

Alanine $\quad 30.9$ 


\section{ACCEPTED MANUSCRIPT}

1: chemical scores calculated with FAO/WHO reference protein as the base.

2: chemical scores calculated with amino acid requirements as per NRC (1993).

a: Essential amino acids of Reference Protein according to FAO/WHO.

b: Essential amino acid requirements of common carp according to NRC (1993).

c: Sum of tyrosine and phenylalanine contents. 